\title{
Plant diversity in betel leaf agroforestry of South Meghalaya, Northeast India
}

\author{
H. TYNSONG ${ }^{1, \boldsymbol{v}}$, B.K. TIWARI ${ }^{2}$, M. DKHAR ${ }^{3}$ \\ ${ }^{1}$ Ministry of Environment, Forest and Climate Change, North Eastern Regional Office. Shillong 793021, Meghalaya, India. \\ vemail: herotynsong@yahoo.com \\ ${ }^{2}$ Department of Environmental Studies, North-Eastern Hill University, Shillong 793022, Meghalaya, India \\ ${ }^{3}$ Union Christian College Umiam, Ri Bhoi, Shillong 793122. Meghalaya, India \\ Manuscript received: 16 January 2018. Revision accepted: 26 March 2018.
}

\begin{abstract}
Tynsong H, Tiwari BK, Dkhar M. 2018. Plant diversity in betel leaf agroforestry of South Meghalaya, Northeast India. Asian J For 2: 1-11. Large areas of lowland tropical forests in South Meghalaya, India have been converted into betel leaf agroforestry systems by the tribal people living in the area. Traditional betel leaf agroforestry still maintains high biodiversity and structurally complex shade canopies compared to other agricultural lands despite changes natural forests. Yet, it is not clear the state of biodiversity in betel leaf agroforestry compared to that in natural forests. This study aimed to assess plant diversity of betel leaf agroforestry in South Meghalaya, India and to compare it with a nearby natural forest. A total of 160 plant species were recorded in natural forests out of which 75 were trees, 40 shrubs, and 45 herbs, while in betel leaf agroforestry, a total of 159 plant species, 94 trees, 17 shrubs and 48 herbs were recorded. A total of 34 tree species, 13 shrub species, and 14 herb species were found in the two land uses. All the plant species were native species. The results of the study suggest that the conversion of natural forest into betel leaf agroforestry in South Meghalaya has no significant impact on tree and herb diversity. However, the basal area and density were affected to some extent. The land-use change had also affected the density and diversity of shrubs. The study concludes that betel leaf agroforestry in South Meghalaya developed by the indigenous War Khasi tribe through experiential learning over several generations has emerged as a fairly sustainable agroforestry system causing minimal impact on plant diversity.
\end{abstract}

Keywords: Betel leaf agroforest, cash crop, natural forest, South Meghalaya

\section{INTRODUCTION}

Biodiversity cannot be conserved effectively if conservation strategies are restricted to protected natural ecosystems alone (Moguel and Toledo 1999). Ryan (1992) reported that there are only about 7000 protected areas in the world, covering approximately 650 million ha and representing less than $5 \%$ of the earth's land surface. While the rest of terrestrial environments are affected by human activities, including agriculture and other developmental works.

Forest ecosystems can range from intact natural forests to slightly-disturbed forests to monoculture industrial plantations. The area under natural and semi-natural forests is decreasing by 13 million ha annually (FAO 2006). Contrary to this, the average annual rate of forest plantation establishment is 5 million ha (FAO 2014). Among such variety form of forestry landscapes, there is the traditional land-use system that combines agriculture and forestry (often so-called agroforestry) under indigenous management which provides relatively high and sustainable economic benefits with a seemingly diversified, productive system.

Most research in ecology and biodiversity has been focused on undisturbed ecosystems, while human-impacted and managed ecosystems have not received equal attention. Man-made landscapes that are part of the indigenous agricultural practices, such as agroforestry, home gardens, polycultures, also contribute a great deal in biodiversity conservation (Toledo 1990; Tynsong and Tiwari 2011).
Toledo et al. (1994) and Tiwari et al. (2017) reported that there is increasing evidence that landscapes under indigenous and local knowledge-based management systems maintain and even improve biodiversity. There are indications that the area under agroforestry systems will continue to increase, making it important to assess its potentials to fulfill biological conservation as well as its economic purpose. The question is whether agroforestry systems can harbor biodiversity which is similar to that in natural forests or not.

Northeastern India is a part of the Indo-Burma biodiversity hotspot, harboring about $50 \%$ of plant biodiversity of India (ca. 8000 species), of which $31.58 \%$ (ca. 2526 species) is endemic (DE, MEDHI 2014). The region is rich in orchids, ferns, oaks (Quercus spp.), bamboos, rhododendrons (Rhododendron spp.), magnolias (Magnolia spp.), etc. According to Conservation International (2011), IndoBurma is the most threatened hotspot with $5 \%$ original habitat is remaining. Threats to species, sites, and landscapes are immediate and severe (Baltzer et al. 2001; Nooren and Claridge 2001; IUCN 2011). The combination of economic development and an increasing human population is exerting enormous pressure on the region's natural resources, and overexploitation has eradicated species from many areas.

Meghalaya is a region in northeastern India with high biodiversity importance. This area harbors 3128 species of angiosperms which include 1237 endemic species and 53 threatened plant species (Khan et al. 1997). The biodiversity of natural forests of Meghalaya has been 
studied by Tiwari et al. (1998), Upadhaya (2002), Jamir and Pandey (2003) and Tripathi et al. (2006). However, biodiversity of agroforestry has not received due attention.

Betel leaf (Piper betle L.) is an important cash crop in India and Bangladesh with huge demand in the Middle East, Britain, Pakistan, and some African counties (Haider et al. 2013). This huge market demand has acted as a driver for conversion of a large chunk of natural forests into betel leaf-based agroforestry systems in India, Bangladesh, Sri Lanka, Malaysia, Philippines, and East Africa (Arambewela et al. 2005; Nath and Inoue 2009a). Betel leaf is traditionally consumed with slices of areca nut and a thin coating of lime by people of South and Southeast Asia, the Gulf States, and the Pacific islands (Nath and Inoue 2009b). Betel leaf has a trade worth of INR 7000 million in India alone (Balasubrahmanyam et al. 1994), where about 15-20 million people consume betel leaves on a regular basis (Jana 1996). Jeng et al. (2002) reported that worldwide, over 2 billion people consume betel leaf.

Although it changes natural forests, traditional betel leaf agroforestry still maintains high biodiversity and structurally complex shade canopies compared to other agricultural lands. The traditional betel leaf agroforestry is more likely to conserve a significant portion of the original forest biodiversity since the establishment of this land use is never clear-felled trees in the natural forests (Tynsong 2009). With a sustained increase of world betel leaf consumption and growing human population in many of the betel leaf consuming regions, pressures to intensify betel leaf production are likely to increase, which will result in more conversions of natural forests to betel leafbased agroforestry.

In Meghalaya, the farming of plant betel leaf (Piper betle L.) is done without cutting of naturally growing trees or burning the field. Betel leaf grows along with trees, shrubs, and herbs on the same piece of land. During the first year after planting the betel leaf, the farmers prune the canopy of all trees except a few important timber trees, fruit trees, and non-coppicing tree species. The cutting of tree branches is done, so the newly planted betel leaf grown at the base of the trees may receive enough sunlight and nutrients from the decaying leaves and branches of the lopped trees. After three to four months, most trees start sprouting again and after one year the whole plantation looks like a natural forest again. Important timber trees include Michelia cathcartii, Toona ciliata, Cedrela toona, and Schima wallichii, fruit trees include Artocarpus heterophyllus, Gynocardia odorata, and Baccuarea sapida and non-coppicing trees include Macaranga peltata, Macaranga hypoleuca, Lithocarpus elegans, and Ligustrum robustum. The process involved in the cultivation of betel leaf and management of betel leaf agroforestry in Meghalaya is similar to that reported for the Khasia tribes of Bangladesh as described by Saha and Azam (2004) and Haider et al. (2013).

Other agroforestry systems viz., coffee, cocoa, and swidden cultivation have received considerable scientific and public attention for their ability to maintain biodiversity (Perfecto et al. 1996; Moguel and Toledo 1999; Schroth and Harvey 2007), yet the same situation has not happened on betel leaf agroforestry systems. Only a handful of researchers from Bangladesh and Sri Lanka have reported biodiversity of betel leaf agroforestry systems (Alam and Mohiuddin 1995; Nath et al. 2003; Arambewela et al. 2005; Nath and Inoue 2009b). In South Meghalaya, more than twenty thousand farmers are currently engaged in the cultivation of betel leaf on approximately fifteen thousand hectares of land. There is a noticeable gap in our understanding of the biodiversity of betel leaf agroforestry created and maintained by the local tribal communities of South Meghalaya. The objective of this study was to inventory the plant diversity of betel leaf agroforestry and to compare it with a nearby natural forest of the area.

\section{MATERIALS AND METHODS}

\section{Study area}

The plant diversity survey was conducted in one natural forest (hereafter NF) and one betel leaf agroforestry (hereafter BLA) in South Meghalaya, India. The NF was located in Siatbakon Village (latitude $25^{\circ} 16^{\prime} \mathrm{N}$, longitude 91056' E, altitude $1003 \mathrm{~m}$ asl) and the BLA was located in Nongkwai Village (latitude $25^{0} 20^{\prime} \mathrm{N}$, longitude 91039.54' E, altitude $600 \mathrm{~m}$ asl) (Figure 1). CherrapunjeeMawsynram Plateau, one of the wettest places in the world is located in this region. The mean annual maximum and minimum temperatures are $23^{\circ} \mathrm{C}$ and $13^{\circ} \mathrm{C}$, respectively. The mean annual rainfall is $11565 \mathrm{~mm}$. The slope of the area is predominantly towards the south and the angle of the slope varies between $10^{\circ}$ and $40^{\circ}$. The area has a large number of rivers and rivulets, which drain into the plains of Bangladesh. At the present time, narrow and deep river valleys separate one hill range from the other.

The population density in the studied area is sparse. Horticulture, forestry, and fisheries are the principal occupations of the people. Agriculture is limited to some small valleys where mainly tuber crops are grown. Areca nut, orange, betel leaf, jackfruit, bay leaf, honey and broom grass are the important products of the region. The area is inhabited by War Khasi people, a tribal community having a long tradition of forest conservation. The local people collect, process, and market a large variety of non-timber forest products (NTFPs) and medicinal and aromatic plants (MAPs) such as Cinnamomum tamala, Piper peepuloides, Phrynium capitatum, bamboo, honey, mushrooms, nuts, wild tubers, edible worms, insects and leafy vegetables from the forests (Tynsong et al. 2012).

\section{Data collection}

An extensive survey was carried out during the months of January 2006 to October 2008. The data were collected once in every season of the year for a period of two years. The composition and structure of NF and BLA were determined within $100 \mathrm{~m}^{2}$ plots $(10 \mathrm{~m} \times 10 \mathrm{~m})$ for trees $(\mathrm{dbh} \geq 5 \mathrm{~cm}) ; 25 \mathrm{~m}^{2}$ plots $(5 \mathrm{~m} \times 5 \mathrm{~m})$ for shrubs and $1 \mathrm{~m}^{2}$ plot $(1 \mathrm{~m} \times 1 \mathrm{~m})$ for herbs. The total sampled area for each study site was 1 ha for the tree, 0.05 ha for shrub and 0.01 ha for herbs. Tree species with $>10 \mathrm{~cm}$ diameter at breast height (dbh) were individually counted, measured and numbered. The density and frequency of occurrence of the species per plot were also estimated. 


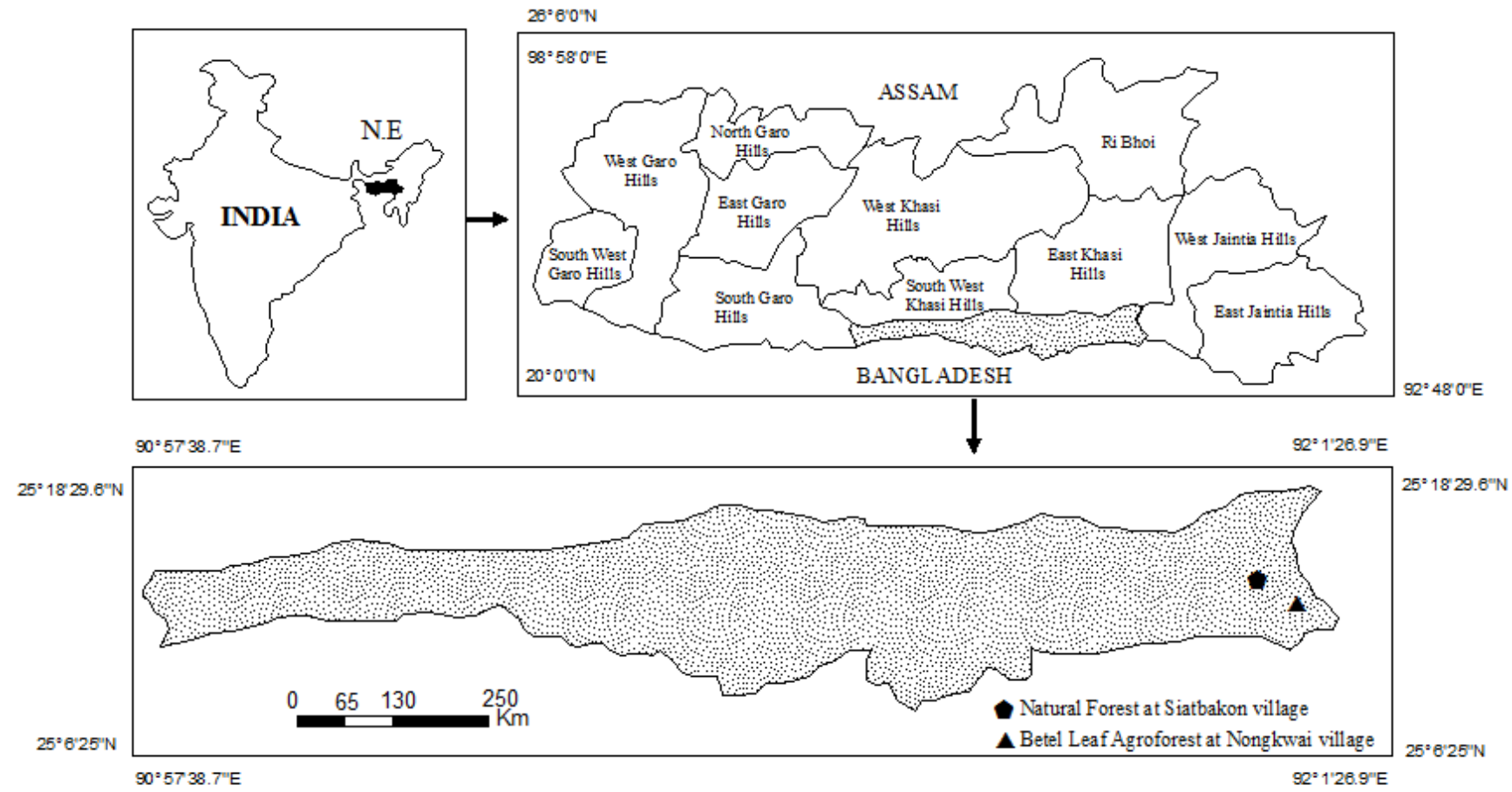

Figure 1. The study sites in natural forest (hereafter NF) and betel leaf agroforestry (hereafter BLA) in South Meghalaya, India

\section{Data analysis}

Plant specimens collected from the two forest types were identified with the help of Flora of Assam (Kanjilal et al.1934-1940) and Flora of Jowai (Balakhrishnan 19811983). The identifications were confirmed by consulting the herbaria at Botanical Survey of India, Northeastern Circle, Shillong, India. The nomenclatures of the species are as per the regional flora. Analysis of variance (ANOVA) and correlation coefficient values (r) was calculated using Statistica Version 6 (Serial no: BX1117619309D60).

Basal area: The basal area of each overstory tree was calculated using equation (1). The basal area values were then extrapolated to per hectare basis.

$$
\mathrm{BA}=\pi \mathrm{D}^{2}
$$

\section{Where:}

BA : basal area $\left(\mathrm{m}^{2} \mathrm{ha}^{-1}\right)$;

D : diameter at breast height $(\mathrm{cm})$; and

$\Pi \quad$ : pi (3.142).

Frequency, density, and abundance: The frequency, density, and abundance of the species were determined following the methods of Misra (1968) and MullerDombois and Ellenberg (1974). The frequencies of occurrence were obtained to ascertain species abundance and species evenness. The following biodiversity indices were computed.

Simpson index of dominance (D): Simpson index of dominance (D) (Simpson 1949) was obtained using equation (2):

$$
\mathrm{D}=\sum(\mathrm{ni} / \mathrm{N})^{2}
$$

Where:

ni : number of individuals of ith species.

$\mathrm{N}$ : total number of individuals of all the species.

Species relative density (RD): This refers to the number of individuals of a given species divided by the total number of individuals of all species. This was obtained using equation (3):

$$
\mathrm{RD}=\underset{\mathrm{N}}{\mathrm{n}_{\mathrm{i} \times} 100}
$$

Where:

$\mathrm{RD}$ : relative density;

$\mathrm{n}_{\mathrm{i}} \quad$ : number of individuals of species;

$\mathrm{N}$ : total number of individuals in the entire population

Importance value index (IVI): For tree species, it was obtained by summing RD and RDo, and then dividing it by 2 as given by Equation (4).

$$
\mathbf{I V I}=\frac{\mathrm{RD}+\mathrm{RDo}}{2}
$$

For shrub and herb: IVI $=$ relative frequency + relative density.

The Shannon-Wiener diversity index $\left(\mathbf{H}^{-}\right)$. ShannonWiener diversity index (Shannon and Wiener 1963) was obtained by using Equation (5):

Shannon-Wiener diversity index: 
$\mathrm{H}^{-}={ }^{-} \sum(\mathrm{ni} / \mathrm{N}) \log _{\mathrm{e}}(\mathrm{ni} / \mathrm{N})$

Where:

ni : IVI of each species and

$\mathrm{N}$ : total IVI

Species evenness (E): Pielou's evenness index (Pielou 1975) was obtained by using equation 6 .

Pielou's evenness index (E):

$\mathrm{E}=\sum(\mathrm{ni} / \mathrm{N}) \log _{\mathrm{e}}(\mathrm{ni} / \mathrm{N}) / \log _{\mathrm{e}} \mathrm{S}$

Where:

ni : IVI of each species,

$\mathrm{N}$ : total IVI and

S : Number of species

\section{RESULTS AND DISCUSSION}

\section{Plant diversity}

In the natural forest site (NF), a total of 160 plant species were recorded of which 75 were trees, 40 shrubs, and 45 herbs, while in the betel leaf agroforestry site (BLA) a total of 159 plant species, 94 trees, 17 shrubs and 48 herbs were recorded. A total of 34 tree species, 13 shrub species, and 14 herb species were present in both forest types. All the plant species encountered were native species (Table S1). For shrub components, species richness, number of families and number of genera were significantly higher in NF as compared to BLA. However, for tree and herb components, the number of families, number of genera and Shannon Diversity Index were slightly higher in BLA as compared to NF (Table 1). The similarity between NF and BLA for trees, shrubs and herbs species was $43.34 \%, 37.93 \%$, and $38.32 \%$ respectively. The one-way analysis of variance (ANOVA) showed significant variation $(\mathrm{P} \leq 0.001)$ of tree, shrub, and herb between NF and BLA. The correlation coefficient values (r) showed a positive significant correlation between tree $(\mathrm{r}=$ $0.87, \mathrm{P} \leq 0.001)$, shrub $(\mathrm{r}=1.00, \mathrm{P} \leq 0.001)$ and herb $(\mathrm{r}=$ $1.00, \mathrm{P} \leq 0.001)$.

Three dominant families of trees in NF were Lauraceae (11 species), Fagaceae ( 8 species) and Euphorbiaceae ( 8 species), while dominant families of trees in BLA were
Euphorbiaceae (12 species) Lauraceae (12 species) and Moraceae ( 8 species). For shrubs, three dominant families in NF were Rubiaceae ( 9 species), Moraceae (4 species) and Poaceae (3 species), while in BLA they were Rubiaceae (6 species), Arecaceae (2 species) and Urticaceae ( 2 species). For herbs, three dominant families in NF included Zingiberaceae (5 species), Rubiaceae (4 species) and Melastromaceae (4 species), while dominant families in BLA included Asteraceae (5 species), Rubiaceae (4 species) and Poaceae (3 species). We encountered 24 families of trees, 9 families of shrubs and 9 families of herbs present in both forest types.

Tree species with high IVI in each forest type were: Lithocarpus fenestatus, Lithocarpus elegans, and Sarcosperma griffithii (NF); Duabanga grandiflora, Sarcosperma griffithii, and Ficus glomerata (BLA). The ten most important tree species in the two forest types are given in Table 2. A list of endemics (E) and rare (R) species found in both the forest types is given in Table 3 .

\section{Main uses of plants in betel leaf agroforestry}

All 94 tree species recorded in BLA were maintained by local people as supporting trees for betel leaf to grow. However, it was observed that most preferred tree species well supporting the growth of betel leaf include Artocarpus heterophyllus, Duabanga grandiflora, Ficus glomerata, Saraca indica and Sarcosperma griffithii. It was also observed that in BLA, local people preserved the plant species for various purposes. Based on the usage patterns, the plant species present in the BLA were grouped into ten broad categories of usage, namely as, (i) timber divided into: high-value timber (HT) and low-value timber (LT), (ii) fuelwood divided into: high-value fuelwood (HFW) and low-value fuelwood (LFW), (iii) edible stuff (E), (iv) medicinal stuff (M), (v) tool-making stuff (T), (vi) ornamental stuff $(\mathrm{O})$, (vii) craft $(\mathrm{C})$, (viii) packing leaf (PC), (ix) latex producing plant (L) and (x) nonspecific use (NSU). Edible plants included: fruit, vegetable, and seed. In BLA as a whole, the usages were 21 as timber trees (HT $=10$ and $\mathrm{LT}=11), 51$ as fuelwood $(\mathrm{HFW}=20$ and $\mathrm{LFW}=$ 31), 15 as edible stuff, 17 as medicinal stuff, 40 with nonspecific uses and as making tools stuff, ornamental stuff, craft, spice stuff, packing leaf and latex producing plant for the rests with a total of 15 plant species (Table 4).

Table 1. Diversity and community characteristics of plant species in natural forest (NF) and betel leaf agroforestry (BLA) in South Meghalaya, India

\begin{tabular}{lcccccc}
\hline \multirow{2}{*}{ Parameter } & \multicolumn{3}{c}{ NF } & & \multicolumn{2}{c}{ BLA } \\
\cline { 2 - 7 } & Tree & Shrub & Herb & Tree & Shrub & Herb \\
\hline Sampling size (ha) & 1 & 0.4 & 0.02 & 1 & 0.4 & 0.02 \\
Number of families & 33 & 21 & 27 & 41 & 13 & 31 \\
Number of genera & 61 & 33 & 37 & 78 & 21 & 42 \\
Species richness & 75 & 40 & 45 & 94 & 17 & 48 \\
Density $\left(\right.$ ha $\left.^{-1}\right)$ & 1972 & 19280 & 347563 & 1788 & 7660 & 423688 \\
Basal area $\left(\mathrm{m}^{2} \mathrm{ha}^{-1}\right.$ ) & 52.26 & - & - & 50.06 & - & - \\
Species evenness index (E) & 0.83 & 0.90 & 0.93 & 0.90 & 0.45 & 0.95 \\
Shannon diversity index (H) & 3.87 & 3.35 & 3.55 & 4.10 & 2.70 & 3.68 \\
\hline
\end{tabular}


Table 2. Ten most important tree species in natural forest and betel leaf agroforestry

\begin{tabular}{|c|c|c|c|c|}
\hline Tree species & Freq. $(\%)$ & DBH (cm) & Basal Area $\left(\mathbf{m}^{2} \mathbf{h a}^{-1}\right)$ & IVI \\
\hline \multicolumn{5}{|l|}{ NF } \\
\hline Lithocarpus fenestatus (Roxb.) Rehder & 41 & 1.58 & 4.96 & 40.66 \\
\hline Lithocarpus elegans (Blume.) Soep. & 48 & 1.37 & 4.29 & 30.8 \\
\hline Sarcosperma griffithii Benth. & 51 & 0.94 & 2.94 & 16.58 \\
\hline Machilus bombycina King. & 38 & 0.80 & 2.52 & 12.35 \\
\hline Schima walichii Choisy. & 22 & 0.68 & 2.12 & 11.66 \\
\hline Quercus lanceofolia Roxb. & 29 & 0.65 & 2.04 & 10.51 \\
\hline Castanopsis hystrix A.DC. & 34 & 0.58 & 1.84 & 10.48 \\
\hline Helicia erratica Hk.f. & 40 & 0.58 & 1.82 & 8.76 \\
\hline Castenea sativa Miller. & 19 & 0.51 & 1.61 & 8.5 \\
\hline Quercus spicata Smith. & 16 & 0.49 & 1.55 & 6.02 \\
\hline \multicolumn{5}{|l|}{ BLA } \\
\hline Duabanga grandiflora (Roxb. Ex DC.) Walp. & 33 & 50.94 & 11.82 & 32.78 \\
\hline Sarcosperma griffithii Benth. & 58 & 79.59 & 5.97 & 16.36 \\
\hline Ficus glomerata Roxb. & 28 & 18.78 & 3.66 & 10.99 \\
\hline Ficus benjamina L. var. comosa Kurtz. & 8 & 68.98 & 2.24 & 10.51 \\
\hline Phoebe cooperiana U.N.Kanjilal ex A.Das.Nov.sp. & 30 & 17.37 & 2.18 & 8.7 \\
\hline Wrightia tomentosa Roem \& Sch. & 33 & 31.84 & 2.07 & 8.19 \\
\hline Artocarpus lakoocha Roxb. & 40 & 17.51 & 1.69 & 7.01 \\
\hline Toona ciliata Roem. & 33 & 28.65 & 1.68 & 6.86 \\
\hline Caryota urens $\mathrm{L}$. & 28 & 22.29 & 1.17 & 6.85 \\
\hline Adenanthera pavonina $\mathrm{L}$. & 40 & 21.51 & 1.16 & 6.39 \\
\hline
\end{tabular}

Table 3. Endemic and rare plant species present in the natural forest and betel leaf agroforestry

\begin{tabular}{|c|c|c|c|}
\hline Plant species & Family & Status & Forest stands \\
\hline \multicolumn{4}{|l|}{ Tree } \\
\hline Acer oblongum Wall. & Aceraceae & $\mathrm{R}$ & NF \\
\hline Citrus latipes (Swingle.)Tanaka. & Rutaceae & $\mathrm{E}, \mathrm{R}$ & NF \\
\hline Cyathea gigantea (Wall ex Hook.) Holttm. & Cyatheaceae & $\mathrm{R}$ & NF \\
\hline Daphniphyllum himalayense Muell. & Euphorbiaceae & $\mathrm{E}$ & $\mathrm{NF}$ \\
\hline Drimycarpus racemosus Hk.f & Anacardiaceae & $\mathrm{E}$ & BLA \\
\hline Erythroxylon kunthianum Wall. & Malpighiaceae & $\mathrm{E}$ & NF \\
\hline Euonymus lawsonii Clarke \& Prain. & Celastraceae & E & BLA \\
\hline Ilex embelioides $\mathrm{Hk} . \mathrm{f}$. & Aquifoliaceae & $E, R$ & BLA \\
\hline Sarcosperma griffithii Benth. & Sapotaceae & $\mathrm{R}$ & NF \& BLA \\
\hline \multicolumn{4}{|l|}{ Shrub } \\
\hline Ardisia griffithii C.B.Clarke. & Myrsinaceae & $\mathrm{E}$ & NF \\
\hline Ixora subsissillis Wall. & Rubiaceae & $\mathrm{E}$ & NF \& BLA \\
\hline Mahonia pycnophylla Fedde. & Berberidaceae & $\mathrm{E}$ & NF \\
\hline Rubus khasianus Cordat. & Rosaceae & $\mathrm{E}$ & NF \\
\hline \multicolumn{4}{|l|}{ Herb } \\
\hline Eriocaulon cristatum Mast. & Eriocaulaceae & $\mathrm{E}$ & NF \\
\hline Impatiens tripetala DC. & Balsaminaceae & $\mathrm{E}$ & BLA \\
\hline Osbekia capitata Benth. & Melastromaceae & $\mathrm{E}$ & $\mathrm{NF}$ \\
\hline Sonerilla khasiana Dyer. & Melastromaceae & $\mathrm{E}, \mathrm{R}$ & NF \\
\hline
\end{tabular}

Note: NF- natural forest, BLA-betel leaf agroforestry, E- Endemic, R- Rare

\section{Discussion}

Tree species diversity and richness $\left(\mathrm{H}^{\prime}=4.10 ; 94\right.$ species $)$ in BLA was higher than that in $\mathrm{NF}\left(\mathrm{H}^{\prime}=3.87 ; 75\right.$ species $)$. Also, herb species diversity and richness in BLA $\left(\mathrm{H}^{\prime}=\right.$ $3.68 ; 48$ species) were higher than $\mathrm{NF}\left(\mathrm{H}^{\prime}=3.55 ; 45\right.$ species). However, shrub species diversity and richness $\left(\mathrm{H}^{\prime}\right.$ $=2.70 ; 17$ species) in BLA was slightly lower than that in
$\mathrm{NF}\left(\mathrm{H}^{\prime}=3.35 ; 40\right.$ species) (Table 1). A comparison between the tree species richness in BLA of South Meghalaya recorded in this study with other agroforestry systems shows that tree diversity of BLA is significantly higher (94 tree species) than cocoa agroforestry in southern Cameroon (21 tree species), betel leaf agroforestry in Bangladesh (61 tree species) (Nath et al. 2003) and betel 
nut agroforestry in South Meghalaya (83 tree species) (Tynsong and Tiwari 2010) but it is lower than that in the coffee farms in Veracruz, Mexico (Lopez-Gomez et al. 2008). Species richness for herb in BLA in South Meghalaya recorded in this study (48 species) is similar to cocoa agroforestry in south Cameron (48 herb species) (Sonwa et al. 2007) and slightly higher than the betel nut agroforestry in South Meghalaya (41 herb species) (Tynsong and Tiwari 2010). Tree species in BLA are more diverse as compared to traditional agroforestry in Dellomenna District, Southeastern Ethiopia ( $\mathrm{H}^{\prime}=2.53$ to 2.73) (Molla and Kewessa 2015), home garden in Thailand $\left(\mathrm{H}^{\prime}=0.9\right.$ to 2.7$)$ (Gajaseni and Gajaseni 1999) and traditional agroforestry in Kerala in India $\left(\mathrm{H}^{\prime}=1.12\right.$ to 3 ) (Kumar et al. 1994).

Tree basal area in BLA $\left(50.05 \mathrm{~m}^{2} \mathrm{ha}^{-1}\right)$ was marginally less than NF (52.26) (Table 1). However, in comparison with other agroforestry systems, the BLA has higher tree basal area. For example, in cocoa agroforestry and mixed food crops agroforestry in Southeastern Ghana, the basal area was recorded at $8.4 \mathrm{~m}^{2} \mathrm{ha}^{-1}$ and $8.2 \mathrm{~m}^{2} \mathrm{ha}^{-1}$ respectively (Asase and Tetteh 2010). It is also higher than in cocoa plantations in Indonesia (11.9 to $20.5 \mathrm{~m}^{2} / \mathrm{ha}$ ) (Merijn et al. 2007) and in cocoa plantations in the southern province of Cameroon (29.7 to $42.6 \mathrm{~m}^{2} / \mathrm{ha}$ ) (Van Gemerden 2004). Our results suggest that a better stock of forest tree species was maintained in the betel leaf agroforestry than that in the natural forest of the area. We also observed that tree species such as Trema polytoria, Macaranga denticulata, Macaranga peltata, Adenanthera pavonina, Ficus roxburghii and Wrightia tomentosa were found only in BLA.

Furthermore, some light-demanding second-storey tree species such as Trema polytoria, Macaranga denticulata, and Macaranga peltata grew luxuriantly in BLA and were absent in NF due to the higher density of trees resulting in the lower sunlight. Higher herb species diversity in BLA may be attributed to the fact that it was dominated by lightdemanding plants, specifically those belonging to Asteraceae, Rubiaceae, and Poaceae. Thus in BLA, the species composition of trees and herbs seem to be directly related to the availability of light.

Table 4. Number of plant species and their main uses in BLA in South Meghalaya, India

\begin{tabular}{llc}
\hline Main uses & & No of plant species \\
\hline Timber & High value & 10 \\
& Low value & 11 \\
Fuelwood & High value & 20 \\
& Low value & 31 \\
Edible & & 15 \\
Medicinal & 17 \\
Tool & 6 \\
Ornamental & 5 \\
Craft & 2 \\
Packing Leaf & 1 \\
Latex Producing Plant & 1 \\
No Specific Use & 40 \\
Total & 159 \\
\hline
\end{tabular}

A similar finding was reported in traditional cocoa forest gardens by Bisseleua et al. (2008). The lower number of shrub species in BLA could be explained by the traditional management practices of BLA by local people, such as by the weeding out of shrubs growing close to betel leaf plants twice a year by farmers, so the betel leaf have sufficient space and nutrients to grow. Even though in BLA all tree species were maintained as supporting trees, we observed that high percentage of highly economical useful plant species were retained by purpose. The preference for multipurpose tree species is understandable in the context that the owners of the agroforestry depend on such plants for timber, food, medicine, and fuelwood (Tiwari et al. 2004). Motiur et al. (2006) also found that agroforestry in Bangladesh supply important forest products like fruit, fuelwood, timber and bamboo to meet household demands. Besides supporting trees, tree species were maintained mainly for timber, fuelwood, and edible stuff purposes. Artocarpus heterophyllus, Cedrela toona, Duabanga grandiflora, and Schima wallichii were preferred timber trees, while Macaranga denticulata, Macaranga hypoleuca, Macaranga peltata, Quercus dealbata, and Quercus lanceofolia were most preferred as fuelwood trees. A total of 17 medicinal plant species were recorded in BLAs. BLAs are also the habitat for 14 endemic and 6 rare plants. Thus, these manmade ecosystems contribute to biodiversity conservation, while at the same time they also provide goods and services to the local inhabitants.

In conclusion, the betel leaf agroforestry harbors plant diversity comparable to the natural forests and provides habitat for endemic and rare plant and animal species. The land-use change has a negligible impact on tree and herb diversity. However, it has a significant impact on density and diversity of shrub species. Betel leaf agroforestry in South Meghalaya is best-suited land use practice with minimal impact on plant diversity and forest community structure. We conclude that for a more robust study and conclusions regarding the impact of betel leaf agroforestry on plant diversity, further research needs to be carried out across the region.

\section{ACKNOWLEDGEMENTS}

We are deeply indebted to the Scientist Incharge, BSI, Eastern Circle, Shillong, India for allowing us to consult the herbaria and also for deputing staff to help in the identification of plant specimens. The help of Shri Mritunjay Kar, Technical Assistant, MoEF \& CC, Shillong in preparation of map is gratefully acknowledged. The authors declare that there is no conflict of interest regarding the publication of this paper. The opinion expressed in the paper is of authors and not of the organization/institute to which they belong. The first author is thankful to the Additional Principal Chief Conservator of Forests (C), MoEF \& CC, Shillong for his constant encouragement. 


\section{REFERENCES}

Alam MK, Mohiuddin M.1995. Conservation of tree diversity through betel-leaf (Piper betel) based Agroforestry in Sylhet, Bangladesh. J For Science 24: 49-53.

Arambewela L, Kumaratunga KGA, Dias K. 2005. Studies on Piper betle of Sri Lanka. J Nat Sci Found Sri Lanka 33: 133-139. DOI: 10.4038/jnsfsr.v33i2.2343

Asase A, Tetteh DA. 2010. The role of complex agroforestry systems in the conversation of forest tree diversity and structure in southeastern Ghana. Agrofor Syst 79: 355-368. DOI: 10.1007/s10457-010-9311-1

Balakrishnan NP. 1981-1983. Flora of Jowai, Meghalaya. Vol. I \& II. Botanical Survey of India, Howrah, India.

Balasubrahmanyam VR, Johri JK, Rawat AKS, Tripathi RD, Chaurasia RS. 1994. Betelvine (Piper betle L.). National Botanical Research Institute, Lucknow, India.

Baltzer MC, Nguyen TD, Shore RG (eds.). 2001. Towards a vision for biodiversity conservation in the Forests of the Lower Mekong Ecoregion Complex. Hanoi: WWF Indochina Program.

Bisseleua D, Hervé B, Vidal S. 2008. Plant biodiversity and vegetation structure in traditional cocoa forest gardens in southern Cameroon under different management. Biodiv Conserv 17: 1821-1835. DOI: 10.1007/s10531-007-9276-1.

Conservation International. 2011. The world's 10 most threatened Forest Hotspots. Conservation International, New York.

De LC, Medhi RP. 2014. Diversity and conservation of rare and endemic orchids of North East India - a review. Indian J Hill Farming 27 (1): 138-153.

FAO. 2014. Planted forests. Rome: Food and Agricultural Organization. Food and Agriculture Organization of the United Nations, Rome.

FAO. 2006. Global Forest Resources Assessment 2005-Progress towards sustainable forest management. FAO Forestry Paper 147. Food and Agriculture Organization of the United Nations, Rome.

Gajaseni N, Gajaseni J. 1999. Ecological rationalities of the traditional homegarden system in the Chao Phraya Basin, Thailand. Agrofor Syst 46: 3-23. DOI: 10.1023/A:1006188504677

Haider MR, Khair A, Rahman MM, Alam MK.2013. Indigenous management practices of betel-leaf (Piper betel L.) cultivation by the Khasia community in Bangladesh. Indian J Trad Knowl 12: 231-239.

IUCN [International Union for Conservation of Nature]. 2011. IUCN red list of threatened species. Version 2011.1. http://www.iucnredlist.org [20 November 2017].

Jamir SA, Pandey HN. 2003. Vascular plant diversity in the sacred groves of Jaintia Hills in northeast India. Biodiv Conserv 12: 1497-1510. DOI: $10.1023 / \mathrm{A} \cdot 1023682228549$

Jana BL. 1996. Improved technology for betel leaf cultivation. "Seminarcum-Workshop on Betel leaf Marketing", Directorate of Agricultural Marketing, Digha, Midnapur, West Bengal, India, June 5-6, 1996.

Jeng JH, Chen SY, Liar CH, Tung YY, Lin BR, Hahn LJ, Chang MC. 2002. Modulation of platelet aggregation by areca nut and betel leaf ingredients: Roles of relative oxygen species and cyclooxygenase. Free Radic Biol Med 32: 860-871. DOI: 10.1016/s0891-5849(02)00749-9

Kanjilal UN, Kanjilal PC, Das A, De RN, Bor NL. 1934-1940. Flora of Assam. 5 Vols. Government Press, Shillong, India.

Khan ML, Shaily M, Kamaljit SB. 1997. Effectiveness of the protected area network in biodiversity conservation, a case study of Meghalaya state Biodiv Conserv 6: 853-865. DOI: 10.1023/B:BIOC.0000010406.35667.c0

Kumar BM, George SJ, Chinnamani S. 1994. Diversity, structure and standing stock of wood in the home gardens of Kerala in Peninsular India. Agrofor Syst 25: 243-262. DOI: 10.1007/BF00707463

Lopez-Gomez AM, Williams-Linera G, Manson RH. 2008. Tree species diversity and vegetation structure in shade coffee farms in Veracruz, Mexico. Agri Ecosys Environ 124: 160-172. DOI: 10.1016/j.agee.2007.09.008

Merijn MB, Steffan-Dewenter I, Tscharntke T. 2007. The contribution of cacao agroforests to the conservation of lower canopy ant and beetle diversity in Indonesia. Biodiv Conserv 16: 2429-2444. DOI: 10.1007/s10531-007-9196-0

Misra R. 1968. Ecology Work Book. Oxford and IBH, New Delhi.

Moguel P, Toledo VM. 1999. Biodiversity Conservation in Traditional Coffee Systems of Mexico. Conserv Biol 13: 11-21. DOI 10.1046/j.1523-1739.1999.97153.x

Molla A, Kewessa G. 2015. Woody Species Diversity in Traditional Agroforestry Practices of Dellomenna District, Southeastern Ethiopia: Implication for Maintaining Native Woody Species. Intl J Biodiv DOI: $10.1155 / 2015 / 643031$

Motiur RM, Furukava Y, Kawata I, Rahman M, Alam M. 2006. Role of homestead forest in household economy and factors affecting forest production: a case study in southwest Bangladesh. J For Res 11: 89-97. DOI: $10.1007 / \mathrm{s} 10310-005-0191-6$

Mueller-Dombois D, Ellenberg H. 1974. Aims and Methods of Vegetation
Ecology. John Wiley, New York.

Myers N, Mittermeier R A, Mittermeier CG, Gustava AB, Da F, Kent J. 2000. Biodiversity hotspots for conservation priorities. Nature 403: 853-858. DOI: $10.1038 / 35002501$

Nath TK, Inoue M. 2009b. Forest-based settlement project and its impacts on community livelihood in the Chittagong Hill Tracts, Bangladesh. Intl For Res 11: 394-407.

Nath TK, Inoue M. 2009a. Sustainability Attributes of a Small Scale Betel Leaf Agroforestry System: A Case Study in North-Eastern Hills Forests of Bangladesh. Small Scale For 8: 289-304. DOI: 10.1007/s11842-009-9084-4

Nath TK, Makato I, Islam MJ, Kabir MA. 2003. The Khasia tribe of northeastern Bangladesh, their socio-economic status, hill farming practices and impacts on forest conservation. For Trees Livelihood 13: 297-311. DOI: 10.1080/14728028.2003.9752467

Nooren H, Claridge G. 2001. Wildlife trade in Lao PDR: the end of the game. Netherlands Committee for IUCN, Amsterdam.

Perfecto I, Rice R, Greenberg R, Van Der VM. 1996. Shade coffee: a disappearing refuge for biodiversity. Biodiv Sci 46: 598-608.

Pielou EC.1975. Population and community ecology. Principles and Methods. Gordon and Breach Science Publishers Inc., New York.

Ryan JC. 1992. Life Support: Conserving Biological Diversity. Worldwatch Paper 108. Worldwatch Institute, Washington, D.C.

Saha N, Azam MA. 2004. The indigenous hill-farming system of Khasia tribes in Moulvibazar district of Bangladesh: Status and impacts. Small-Scale For Econ Manag Pol 3: 273-281. DOI: 10.1007/s1 1842-004-0019-9

Schroth G, Harvey CA. 2007. Biodiversity conservation in cocoa production landscapes: an overview. Biodiv Conserv 16: 2237-2244. DOI: $10.1007 / \mathrm{s} 10531-007-9195-1$

Shannon C E, Wiener W.1963. The mathematical theory of communication. University Illinois Press, Urbana, IL.

Simpson EH. 1949. Measurement of diversity. Nature 163: 688

Sonwa DJ, Nkongmeneck BA, Weise SF, Tchatat M, Adesina AA, Janssens MJJ. 2007. Diversity of plants in cocoa agroforestry in the humid forest zone of Southern Cameroon. Biodiv Conserv 16: 2385-2400. DOI: $10.1007 / \mathrm{s} 10531-007-9187-1$

Takhtajan A. 1988. Floristic Region of the World. Bishen Singh Mahandra Pal Singh, Dehradun, India

Tiwari BK, Barik SK, Tripathi RS. 1998. Biodiversity value, status and strategies for conservation of sacred groves of Meghalaya, India. Ecosyst Health 4: 20-32. DOI: 10.1046/j.1526-0992.1998.00068.x

Tiwari BK, Tynsong H, Dkhar M. 2017. Traditional knowledge-based conservation and utilization of bioresources by War Khasi tribe of Meghalaya, India. In: Madhav K, Rosemary H, Dayuan X, et al. (eds.) Knowing our Lands and Resources: Indigenous and Local Knowledge and Practices related to Biodiversity and Ecosystem Services in Asia. Knowing our Lands and Resources 10. UNESCO, Paris.

Tiwari BK, Tynsong H, Rani S. 2004. Medicinal and aromatic plants: Medicinal plants and human health. In: Burley J, Evans J, Youngquist JA (eds.). Encyclopedia of Forest Sciences. Elsevier, Oxford, UK.

Toledo VM, Ortiz B, Medellín S. 1994. Biodiversity islands in a sea of pastureland: indigenous resource management in the humid tropics of Mexico. Etnoecológica 3: 37-50.

Toledo, VM. 1990. The ecological rationality of peasant production. In Altieri M, Hecht S (ed.). Agroecology and Small-farm Development. CRC Press, Boca Raton, Florida.

Tripathi OP, Pandey HN, Tripathi RS. 2006. Tree diversity and community characteristics of the sub-tropical evergreen forest in the buffer and core zones of Nokrek biosphere reserve, Northeast India. In: Pandey HN, Barik SK (eds.). Ecology, Diversity and Conservation of Plants and Ecosystems in India. Regency Publication, New Delhi.

Tynsong H, Tiwari BK. 2011. Diversity and population characteristics of woody species in natural forests and arecanut agroforestry of South Meghalaya, Northeast India. Trop Ecol 52: 243-252.

Tynsong H, Tiwari BK Dkhar M. 2012. Contribution of NTFPs to cash income of the War Khasi community of southern Meghalaya, Northeast India. For Stud China 14: 47-54. DOI: 10.1007/s11632-012-0104-7

Tynsong H, Tiwari BK. 2010. Diversity of plant species in Arecanut agroforestry in the tropical evergreen forest of South Meghalaya, Northeast India. J For Res 21: 281-286. DOI: 10.1007/s11676-010-0072-5

Tynsong H. 2009. Plant diversity and NTFP management in community forests of War area Meghalaya. [Dissertation]. North-Eastern Hill University, Shillong, India.

Upadhaya K. 2002. Studies on plant biodiversity and ecosystem function of sacred groves of Meghalaya. [Dissertation]. North-Eastern Hill University, Shillong, India.

Van Gemerden BS. 2004. Disturbance, diversity and distributions in Central African rain forest. [Dissertation], Wageningen University, The Netherlands. 
Table S1: Plant species, their families, density (individual ha ${ }^{-1}$ ) recorded in Natural Forest (NF) and Betel Leaf Agroforest (BLA) of South Meghalaya, Indonesia

\begin{tabular}{|c|c|c|c|c|c|c|c|}
\hline \multirow{2}{*}{ Tree species } & \multirow{2}{*}{ Family } & \multicolumn{2}{|c|}{ Frequency } & \multicolumn{2}{|c|}{ Density } & \multicolumn{2}{|l|}{ IVI } \\
\hline & & $\mathrm{NF}$ & BLA & NF & BLA & $\mathbf{N F}$ & BLA \\
\hline Acer oblongum Wall. & Aceraceae & 3.00 & - & 4 & - & 0.48 & - \\
\hline Actinodaphne abovata (Nees.) Blume. & Lauraceae & 4.00 & 10.00 & 7 & 16 & 0.77 & 2.93 \\
\hline Actinodaphne angustifolia Nees. & Lauraceae & 3.00 & - & 7 & - & 0.61 & - \\
\hline Adenanthera pavonina $\mathrm{L}$. & Mimosaceae & - & 40.00 & - & 44 & - & 6.39 \\
\hline Aesculus assamica Griff. & Hippocastanaceae & - & 7.50 & - & 6 & - & 1.02 \\
\hline Aglaia perviridis Hiern. & Meliaceae & - & 37.50 & - & 36 & - & 5.29 \\
\hline Alstonia scolaris Brown. & Apocynaceae & - & 10.00 & - & 8 & - & 1.32 \\
\hline Amoora rohituka W\&A. & Meliaceae & - & 12.50 & - & 10 & - & 1.71 \\
\hline Antidesma khasianum Hk.f. & Euphorbiaceae & - & 15.00 & - & 12 & - & 2.10 \\
\hline Aporosa dioica (Roxb.) Muell. Arg. & Euphorbiaceae & 11.00 & 7.50 & 18 & 6 & 2.24 & 1.03 \\
\hline Ardisia floribunda Wall. & Myrsinaceae & 16.00 & - & 42 & - & 4.48 & - \\
\hline Artocarpus heterophyllus Ham. & Moraceae & - & 12.50 & - & 20 & - & 2.45 \\
\hline Artocarpus lakoocha Roxb. & Moraceae & - & 40.00 & - & 36 & - & 7.01 \\
\hline Baccuarea sapida (Roxb.) Muell. & Euphorbiaceae & 24.00 & 20.00 & 46 & 18 & 5.52 & 3.34 \\
\hline Bambusa tulda Roxb. & Poaceae & 12.00 & - & 58 & - & 5.82 & - \\
\hline Bambusa vulgaris Schrad. & Poaceae & - & 2.50 & - & 80 & - & 5.06 \\
\hline Beilschmiedia brandisii $\mathrm{Hk} \mathrm{f}$. & Lauraceae & - & 7.50 & - & 6 & - & 1.78 \\
\hline Bischofia javanica Blume. & Euphorbiaceae & - & 15.00 & - & 12 & - & 2.60 \\
\hline Bombax malabaricum DC. & Malvaceae & - & 2.50 & - & 4 & - & 0.82 \\
\hline Brassaiopsis glomerulata (Blume.) Regel. & Araliaceae & - & 7.50 & - & 14 & - & 1.90 \\
\hline Bridelia monta Willd. & Euphorbiaceae & - & 20.00 & - & 16 & - & 2.67 \\
\hline Calicarpa vestica Wall. ex Cl. & Verbenaceae & - & 12.50 & - & 10 & - & 1.66 \\
\hline Canthium glabrum Blume. & Rubiaceae & 6.00 & - & 11 & - & 1.17 & - \\
\hline Caryota urens $\mathrm{L}$. & Arecaceae & - & 27.50 & - & 26 & - & 6.85 \\
\hline Casearia kurzii C.B.Clarke. & Pittosporaceae & - & 10.00 & - & 8 & - & 1.50 \\
\hline Castanopsis hystrix A.DC. & Fagaceae & 34.00 & - & 59 & - & 10.48 & - \\
\hline Castenea sativa Miller. & Fagaceae & 19.00 & - & 48 & - & 8.50 & - \\
\hline Cedrela toona Roxb. & Meliaceae & - & 7.50 & - & 6 & - & 1.28 \\
\hline Chrysophyllum rozburghii G.Don. & Sapotaceae & 5.00 & - & 7 & - & 0.96 & - \\
\hline Cinnamomum bejolghota Buch.-Ham. & Lauraceae & - & 20.00 & - & 20 & - & 3.27 \\
\hline Cinnamomum camphora F.Nees. & Lauraceae & 9.00 & - & 14 & - & 1.71 & - \\
\hline Cinnamomum tamala Fr. Nees. & Lauraceae & 21.00 & 10.00 & 36 & 12 & 4.86 & 2.24 \\
\hline Citrus latipes (Swingle.)Tanaka. & Rutaceae & 6.00 & - & 6 & - & 1.05 & - \\
\hline Citrus macroptera Lour. & Rutaceae & - & 2.50 & - & 2 & - & 0.36 \\
\hline Cryptocarya amygdalina Nees. & Lauraceae & 12.00 & 15.00 & 20 & 12 & 2.76 & 2.16 \\
\hline Cryptocarya andersoni King. & Lauraceae & - & 25.00 & - & 20 & - & 3.46 \\
\hline Cryptocarya floribunda Nees. & Lauraceae & - & 5.00 & - & 6 & - & 1.30 \\
\hline Cyathea gigantea (Wall ex Hook.) Holttm. & Cyatheaceae & 2.00 & - & 5 & - & 0.37 & - \\
\hline Daphniphyllum himalayense Muell. & Euphorbiaceae & 5.00 & - & 18 & - & 1.72 & - \\
\hline Derris robusta Benth. & Fabaceae & - & 7.50 & - & 10 & - & 1.39 \\
\hline Diospyros kaki L. & Sapotaceae & 8.00 & 35.00 & 11 & 28 & 1.49 & 4.43 \\
\hline Diospyros pilosula Wall. & Ebenaceae & - & 10.00 & - & 8 & - & 1.26 \\
\hline Diospyros sp. & Ebenaceae & - & 10.00 & - & 8 & - & 1.43 \\
\hline Drimycarpus racemosus (Roxb.) Hk.f. & Anacardaceae & - & 10.00 & - & 10 & - & 1.71 \\
\hline Duabanga grandiflora (Roxb. Ex DC.) Walp. & Sonneratiaceae & 6.00 & 32.50 & 15 & 58 & 2.32 & 32.78 \\
\hline Dysoxylum hamiltoni Hiern. & Meliaceae & - & 20.00 & - & 30 & - & 4.14 \\
\hline Ehretia acuminata $\mathrm{Br}$. & Boraginaceae & 7.00 & 10.00 & 10 & 8 & 1.32 & 1.47 \\
\hline Elaeocarpus lancifolius Roxb. & Elaeocarpaceae & - & 7.50 & - & 6 & - & 1.13 \\
\hline Elaeocarpus sikkimensis Mast. & Elaeocarpaceae & - & 17.50 & - & 32 & - & 4.59 \\
\hline Elaeocarpus lancifolius Roxb. & Elaeocarpaceae & 11.00 & - & 22 & - & 2.58 & - \\
\hline Engelhardtia spicata Blume. & Jaglandaceae & 5.00 & 7.50 & 7 & 14 & 0.94 & 1.80 \\
\hline Erythroxylon kunthianum Wall. & Malpighiaceae & 7.00 & - & 10 & - & 1.34 & - \\
\hline Erythroxylum kunthianum Wall. & Malpighiaceae & 7.00 & - & 25 & - & 2.39 & - \\
\hline Euonymus lawsonii Clarke \& Prain. & Celastraceae & - & 10.00 & - & 8 & - & 1.37 \\
\hline Eurya acuminata DC. & Theaceae & 8.00 & 5.00 & 14 & 26 & 1.64 & 1.98 \\
\hline Ficus benjavina L. var.comosa Kurtz. & Moraceae & - & 7.50 & - & 12 & - & 10.51 \\
\hline Ficus faveolata Wall. & Moraceae & 4.00 & 10.00 & 13 & 12 & 1.21 & 1.83 \\
\hline Ficus gibbosa Blume. & Moraceae & - & 12.50 & - & 10 & - & 1.60 \\
\hline Ficus glomerata Roxb. & Moraceae & - & 27.50 & - & 92 & - & 10.99 \\
\hline Ficus hirta Vahl. & Moraceae & 5.00 & - & 5 & - & 0.82 & - \\
\hline Ficus roxburghii Wall. & Moraceae & - & 20.00 & - & 46 & - & 5.72 \\
\hline Ficus sp. & Moraceae & 13.00 & & 27 & & 3.15 & \\
\hline Garcinia gummi-gutta (L.) Roxb. & Clusiaceae & - & 5.00 & - & 4 & - & 0.72 \\
\hline Garcinea spicata Hk.f.. & Guttiferae & 5.00 & - & 13 & - & 1.38 & - \\
\hline Garcinia lanceolarium Dalz. & Guttiferae & 7.00 & - & 12 & - & 1.73 & - \\
\hline Garcinia paniculata (G.Don) Roxb. & Guttiferae & 13.00 & - & 17 & - & 2.42 & - \\
\hline
\end{tabular}


Garuga pinnata Roxb.

Glochidion khasicum Hk.f.

Glochidion thomsoni Hk.f.

Gynocardia odorata R.Br.

Helicia erratica Hk.f.

Hydnocarpus kurzii Warb.

Ilex embelioides $\mathrm{Hk}$.f.

Itea macrophylla Wall.

Knema andamanica Hk.f.

Knema linifolia (Roxb.) Warb.

Ligustrum robustum (Roxb.)Blume.

Lithocarpus elegans (Blume.) Soep.

Lithocarpus fenestatus (Roxb.) Rehder

Litsea citrata Blume.

Litsea elongata Wall.

Litsea laeta Benth. Hk.f.

Litsea leiantha (Kurz) Hk.f.

Litsea semecarpifolia (Wall. ex Nees) Hook.f.

Macaranga denticulata Muell. Arg.

Macaranga peltata (Roxb.) Muell.Arg.

Machilus bombycina King.

Macropanax undulatus (Wall.ex D.Don) Seem.

Magaranga indica Wight.

Magnolia pterocarpa Roxb.

Magnolia sp.

Mallotus ferrugineus Roxb.

Mesua ferrea $\mathrm{L}$.

Michelia cathcartii Hk.f.\&Th.

Morus laevigata Wall.

Musa paradisiaca $\mathrm{L}$.

Myrica esculenta Buch-Ham.ex D.Don.

Myrica nagi Thunb.

Oroxyrum indicum Vent.

Ostodes paniculata Blume.

Pandanus odoratissimus L.

Phoebe cooperiana U.N.Kanjilal ex A.Das.Nov.sp.

Phoebe lanceolata Nees.

Pinus khasya Royle.

Pittosporum glabratum Lindl.

Pterospermum acerifolium Willd.

Quercus dealbata Hk.f.\&Th.

Quercus dilatata Lindle.

Quercus lanceaelia Roxb.

Quercus lanceifolia Roxb.

Quercus spicata Smith.

Rhododendron arboreum $\mathrm{Sm}$.

Sapium baccatum Roxb.

Sapium insigne Benth.

Saprosma ternatum Hk.f.

Saraca indica L.

Sarcosperma griffithii Benth.

Schima walichii Choisy.

Sterculia roxburghii Wall.

Streospermum chelonoides (L.f.) DC.

Styrax serrulatum Roxb.

Symplocos ramosissima Wall.

Tetrameles nudiflora R.Br.

Toona ciliata Roem.

Travesia palmata (Roxb.) Vis.

Trema polytoria Planch.

Unidentified1

Unidentified2

Unidentified3

Unidentified4

Unidentified5

Unidentified6

Villebrunea intigrifolia Gaud.

Wenderhardia tinctoria DC.

Wendlandia paniculata DC

Wrightia tomentosa Roem \& Sch.

Syzygium tetragonum (L.) Skeels.
Burseraceae

Euphorbiaceae

Euphorbiaceae

Flacourtiaceae

Proteaceae

Flacourtaceae

Aquifoliaceae

Saxiferaceae

Myristicaceae

Myristicaceae

Oleaceae

Fagaceae

Fagaceae

Lauraceae

Lauraceae

Lauraceae

Lauraceae

Lauraceae

Euphorbiaceae

Euphorbiaceae

Lauraceae

Araliaceae

Euphorbiaceae

Magnoliaceae

Magnoliaceae

Euphorbiaceae

Clusiaceae

Magnoliaceae

Moraceae

Musaceae

Myricaceae

Myricaceae

Bignoniaceae

Euphorbiaceae

Pandanaceae

Lauraceae

Lauraceae

Pinaceae

Pittosporaceae

Sterculiaceae

Fagaceae

Fagaceae

Fagaceae

Fagaceae

Fagaceae

Ericaceae

Euphorbiaceae

Euphorbiaceae

Rubiaceae

Caesalpiniaceae

Sapotaceae

Theaceae

Sterculiaceae

Bignoniaceae

Styraceae

Symplocaceae

Tetramelaceae

Ochnaceae

Araliaceae

Ulmaceae

Unidentified

Unidentified

Sapotaceae

Unidentified

Guttiferae

Unidentified

Urticaceae

Rubiaceae

Rubiaceae

Apocynaceae

Myrtaceae

$\begin{array}{lll}4.00 & - & 4 \\ 6.00 & 12.50 & 13 \\ - & 10.00 & - \\ - & 22.50 & - \\ 40.00 & 2.50 & 52 \\ - & 7.50 & - \\ - & 7.50 & - \\ 7.00 & - & 21 \\ 2.00 & - & 2 \\ 8.00 & 27.50 & 9 \\ 8.00 & 7.50 & 8 \\ 48.00 & 10.00 & 133 \\ 41.00 & - & 169 \\ 8.00 & - & 11 \\ - & 7.50 & - \\ - & 7.50 & - \\ 3.00 & - & 5 \\ 4.00 & 7.50 & 4 \\ - & 2.50 & - \\ - & 10.00 & - \\ 38.00 & 22.50 & 79 \\ - & 22.50 & - \\ 9.00 & - & 13 \\ 2.00 & & 4\end{array}$

$\begin{array}{lll}14.00 & 5.00 \quad 42\end{array}$

$20.00-$

2.50 -

$25.00 \quad-$

25.00 -

$12.50 \quad-$

9.00

4.00

14.00

2.00

5.00

17.00

9.00

1.00

8.00

12.00

29.00

16.00

1.00

6.00

7.00

-

51.00

22.00

3.00

4.00

14.00

7.00

12.00

27.00

$-$

16.00

$-$

6.00

9.00

2.00

18.00

-

42.00

$-$

$10.00 \quad 25$

12.504

14

$30.00 \quad 24$

$10.00 \quad 17$

- $12.50 \quad 4$

$2.50 \quad-$

$-24$

12.50

5.

$5.00 \quad 53$

5

$\begin{array}{ll}7.50 & 12\end{array}$

$25.00 \quad 9$

12.50

12.50

57.50

10.00

12.50

22.50

$10.00 \quad 25$

- $50 \quad 12$

$32.50 \quad 19$

$\begin{array}{ll}32.50 & 19 \\ - & 37\end{array}$

17.50

15.00

32

15.00

- 21

$\begin{array}{ll}- & 17\end{array}$

-

10.00

$15.00 \quad 37$

7.50 -

$32.50-$

$2.50 \quad 86$

106

64

6

(2)

5

2

37

2

6

10

0.65

$1.37 \quad 1.66$

1.39
$-\quad 1.39$

3.43

\begin{tabular}{ll}
$8.76 \quad 0.35$ \\
$-\quad 1.16$ \\
\hline
\end{tabular}

$\begin{array}{ll}- & 1.33\end{array}$

2.42

0.33

$\begin{array}{ll}1.40 & 4.79\end{array}$

$1.30 \quad 1.17$

$30.80 \quad 1.38$

40.66 -

$1.53-$

$\begin{array}{ll}- & 1.40 \\ - & 1.06\end{array}$

0.60

$0.70 \quad 1.04$

$\begin{array}{ll}0.70 & \\ - & 0.34\end{array}$

$-\quad 0.34$
$-\quad 2.07$

$12.35 \quad 5.46$

12.35
$-\quad 4.82$

1.74

$0.49-$

$4.61 \quad 0.83$

\begin{tabular}{l}
4.61 \\
$-\quad 2.90$ \\
\hline
\end{tabular}

$\begin{array}{ll}- & 3.58 \\ - & 3.87\end{array}$

- $\quad 2.30$

1.61

0.81

3.82

0.33

1.59

3.61

2.52

0.16

-

- 3.06

5.50

10.5

6.02

0.21

2.27

1.61

$-$

$-$

$16.58 \quad 16.36$

$11.66 \quad 1.66$

$0.54 \quad 1.81$

$0.65 \quad 4.41$

$3.06 \quad 1.44$

$1.54-$

$2.46 \quad 6.86$

6.02 
Shrub component

Adenosaeme sp.

Ardisia griffithii C.B.Clarke.

Ardisia sp.

Boehmeria malabarica Wedd.

Calamus arborescence Griff.

Camellia caduca C.B. Clarke.

Cephalostachyium sp.

Cephalostachyum pallidum Munro.

Chloranthus glaber Thunb.

Clerodendron serratum Spreng.

Coffea benghalensis Roxb.

Coffea sp.

Cyathea albosetacea Copel.

Daphne involucrata Wall.

Daphne involucrata Wall.

Dracaena fragrans (L.) Ker-Gawl.

Eupatorium odoratum Spreng.

Eurya japonica Thunb.

Ficus clavata Wall.

Ficus hirta Vahl.

Ficus pyriformis Hook. \&Arn.

Ficus sarmentosa Wall.

Flemingia macrophylla (Willd.) Prain.

Goniothalamus sesquipidalis Hk.f.\&Th.

Hedychium coccineum Buch.-Ham.ex Sm.

Hedychium thyrsiforme Buch.-Ham.ex Sm.

Ixora subsissillis Wall.

Justicia sp.

Laportea crenulata (Roxb) Gaud.

Luculia pinceana Hook.

Mahonia pycnophylla Fedde.

Medinilla rubicunda Blume.

Morinda angustifolia Roxb.

Mussaendra roxburghii Hk.f.

Myrioneuron nutans Kurtz.

Ophiorhiza hispida Hook.f.

Phrynium capitatum Willd.

Phrynium sp.

Phyllanthus debilis Ham.

Pinanga cracilia (Roxb.) Blume.

Psychotria erratica Hk.f.

Rubus khasianus Cordat.

Sylvianthus bracteotus Hk.f.

Thysanolaena maxima (Rozb.)O.Ktze.

Unidentified

Wallichia densiflora Mart.

Zanthoxylum armatum DC.

Total

Herb component

Achyranthes japonica (Miq.) Nakai.

Ageratum conzynoides L.

Ananas bracteatus (Lindl.) Schult. \& Schult. f.

Ananas comosus (L.) Merr.

Andropogon glomeratus Walt.

Anotis wightiana Hk.f.

Anthyrium drepanopterum (Kuntze.) A.Brown.

Begonia josephii A.DC.

Begonia palmata D.Don.

Begonia picta $\mathrm{Sm}$.

Bidens pilosa (Blume.) Sherff.

Bolbitis appendiculata J.Sm.

Borreria articularis (L.f.) F.N. Will.

Borreria pilosa K.Schum

Calanthe masuca (D.Don) Lindl.

Carex vesiculosa Booth.

Centella asiatica (L.) Urban.

Commelina beghalensis $\mathrm{L}$.

$\begin{array}{ll}\text { Rubiaceae } & 20.00 \\ \text { Myrsinaceae } & 10.00 \\ \text { Myrsinaceae } & 10.00 \\ \text { Urticaceae } & 10.00 \\ \text { Arecaceae } & - \\ \text { Theaceae } & 40.00 \\ \text { Poaceae } & 10.00 \\ \text { Poaceae } & 15.00 \\ \text { Chloranthaceae } & 35.00 \\ \text { Verbenaceae } & 55.00 \\ \text { Rubiaceae } & 20.00 \\ \text { Rubiaceae } & 25.00 \\ \text { Cyatheaceae } & 35.00 \\ \text { Thymelaeaceae } & 20.00 \\ \text { Thymeleaceae } & - \\ \text { Agavaceae } & - \\ \text { Asteraceae } & - \\ \text { Theaceae } & 45.00 \\ \text { Moraceae } & 5.00 \\ \text { Moraceae } & 5.00 \\ \text { Moraceae } & 5.00 \\ \text { Moraceae } & 5.00 \\ \text { Fabaceae } & 20.00 \\ \text { Annonaceae } & 10.00 \\ \text { Zingiberaceae } & 5.00 \\ \text { Zingiberaceae } & 20.00 \\ \text { Rubiaceae } & 20.00 \\ \text { Acanthaceae } & 15.00 \\ \text { Urticaceae } & 15.00 \\ \text { Rubiaceae } & 5.00 \\ \text { Berberidaceae } & 5.00 \\ \text { Melastromaceae } & 5.00 \\ \text { Rubiaceae } & 45.00 \\ \text { Rubiaceae } & 5.00 \\ \text { Rubiaceae } & 20.00 \\ \text { Rubiaceae } & 10.00 \\ \text { Marantaceae } & 20.00 \\ \text { Marantaceae } & 35.00 \\ \text { Euphorbiaceae } & 10.00 \\ \text { Arecaceae } & 35.00 \\ \text { Rubiaceae } & 60.00 \\ \text { Rosaceae } & 5.00 \\ \text { Rubiaceae } & - \\ \text { Poaceae } & 35.00 \\ \text { Unidentified } & 20.00 \\ \text { Arecaceae } & 55.00 \\ \text { Rutaceae } & 20.00 \\ & - \\ & \end{array}$

$\begin{array}{ll}- & 260 \\ - & 80 \\ - & 140 \\ 10.00 & 180 \\ 8.00 & - \\ - & 340 \\ - & 400 \\ - & 280 \\ - & 1000 \\ 3.00 & 2020 \\ - & 360 \\ - & 480 \\ - & 440 \\ - & 240 \\ 4.00 & -\end{array}$

-
-
-
1005
1480
-
-
-
-

3.70

1.59

1.90 -

$2.11 \quad 25.10$

- 28.01

$6.47 \quad-$

3.25

3.22

9.30

100

16.95

4.23

4.22

5.43

6.40

3.60

3.00 -

$3.00-$

120

-

-

$-$

$-$

$-$

2.00

4.00

Amaranthaceae

Asteraceae

Bromeliaceae

Bromeliaceae

Poaceae

Rubiaceae

Anthyriaceae

Begoniaceae

Begoniaceae

Begoniaceae

Asteraceae

Lomariosidaceae

Rubiaceae

Rubiaceae

Orchidaceae

Cyperaceae

Apiaceae

Commelinaceae

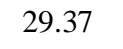

14.38

10.63

15250

-

$\begin{array}{ll}6.88 & - \\ 12.50 & -\end{array}$

13.75

3.75

16.25

8.75

16.88

6.88

$-$

12.50

10.63

11.25

18.75

$-$

- 6.88

6188
7375

4650

$-$

10290

6885

7635

8280

$-$

- 6998

-

2563

6626

7375

1500

15250

10625

6313

17250

8876

20625

53000

16563

11563

4.25

3.42

3.78

0.91

$\begin{array}{ll}3.82 & 6.01\end{array}$

$5.23 \quad 5.57$

2.83 
Costus speciosus (koenig) Smith.

Crassocephalum crepioides (Benth.)Moore.

Crotalaria ferruginea Garh.

Curculigo orchioides Gaertn.

Cyperus compressus L.

Cyperus flavidus Retz.

Cyperus odoratus L.

Drymaria cordata (L.) Roem. \& Schult.

Dryopteris sp.

Elatostema sesquifolium Hassk.

Elatostemma sessile Forst.

Eleusine indica Gaertn.

Eragrostis gangetica (Roxb.) Steud.

Eriocaulon cristatum Mast.

Ficus pumila L.

Galingsoga parviflora Cay.

Gentiana tenella Fries.

Globba clarkii Baker.

Globba racemosa $\mathrm{Sm}$

Globba sp.

Goodyera repens (Ker-Gawl.) Hook.

Hemiphragma heterophyllum Wall.

Hydrocotyle javanica Thunb.

Impatiens balsamina $\mathrm{L}$.

Impatiens benthamii V.Steenis.

Impatiens tripetala DC.

Imperata cylendrica (L.)P.Beauv.

Ipomea purpurea (L.) Roth.

Justicia sp.

Kaulina pteropus (Blume) Nayar.

Knoxia corymbosa Willd.

Miconia prasina (SW.) DC.

Onoclea sensibilis L.

Ophiorrhiza hispida Hk.f.

Ophiorrhiza hispida Hk.f.

Oplismenus compositus P.Beauv.

Osbekia capitata Benth.

Oxalis corniculata $\mathrm{L}$.

Paspalum dilatatum Pior.

Peperomia heyneana Miq.

Peperomia reflexa A.Dietr.

Phryma leptostachya L.

Polygonum hydropiper $\mathrm{L}$.

Polygonum thunbergii Sieb. \& Zucc.

Polystichum aculeatum (L.)Roth.

Pronephrium nudatam (Roxb)Holttum.

Pteris quadriaurita Retz.

Richardia brasiliensis Gomes.

Selaginella chrysocaulos Hk. et. Grev.) Spring.

Sida cordifolia L.

Smithea ciliata Royle.

Sonerila khasiana Clarke.

Sonerilla khasiana Dyer.

Spilanthes paniculata DC.

Srobilanthus sp.

Tacca laevis Roxb.

Torenia diffusa D.Don.

Trillium erectus $\mathrm{L}$.

Urena labata $\mathrm{L}$.

Viola palmaris Ging.

Viola sikkimensis W.Becker

Zingiber rubens Roxb.

Zingiber sp.

Total

Note: '-' : indicates absent

\begin{tabular}{|c|c|c|c|c|c|c|}
\hline Zingiberaceae & 8.13 & - & 4063 & - & 2.38 & - \\
\hline Asteraceae & - & 21.88 & - & 12000 & - & 6.08 \\
\hline Fabaceae & 6.88 & - & 5125 & - & 2.45 & - \\
\hline Hypoxidaceae & 15.63 & 31.88 & 10875 & 29750 & 6.71 & 11.76 \\
\hline Cyperaceae & - & 5.63 & - & 1875 & - & 1.28 \\
\hline Cyperaceae & 35.00 & - & 34625 & - & 16.41 & - \\
\hline Cyperaceae & 16.88 & - & 7813 & - & 5.35 & - \\
\hline Caryophyllaceae & - & 6.88 & - & 3875 & - & 1.94 \\
\hline Dryopteridaceae & 20.63 & - & 19750 & - & 9.48 & - \\
\hline Urticaceae & 6.25 & - & 5063 & - & 2.32 & - \\
\hline Urticaceae & 15.00 & 15.63 & 7000 & 7625 & 4.78 & 4.12 \\
\hline Eragrosteae & - & 15.00 & - & 4500 & - & 3.29 \\
\hline Poaceae & 11.88 & - & 7563 & - & 4.36 & - \\
\hline Eriocaulaceae & 8.75 & - & 6875 & - & 3.59 & - \\
\hline Moraceae & 11.88 & - & 7563 & - & 4.36 & - \\
\hline Asteraceae & - & 8.13 & - & 12125 & - & 4.07 \\
\hline Gentianaceae & 18.13 & - & 11625 & - & 6.68 & - \\
\hline Zingiberaceae & 9.38 & - & 4563 & - & 3.04 & - \\
\hline Zingiberaceae & 15.00 & - & & 10813 & - & 4.78 \\
\hline Zingiberaceae & 10.00 & - & 5688 & - & 3.48 & - \\
\hline Orchidaceae & 6.88 & - & 1750 & - & 1.77 & - \\
\hline Scrophulariaceae & - & 13.13 & - & 8813 & - & 4.03 \\
\hline Apiaceae & 7.50 & 13.75 & 2813 & 6125 & 2.29 & 3.49 \\
\hline Balsaminaceae & - & 12.50 & - & 4000 & - & 2.80 \\
\hline Balsaminaceae & 2.50 & 25.00 & 770 & 12375 & 0.78 & 6.63 \\
\hline Balsaminaceae & 9.38 & 27.50 & 3388 & 11188 & 2.64 & 6.73 \\
\hline Poaceae & - & 7.50 & - & 1938 & - & 1.57 \\
\hline Convolvulaceae & - & 9.38 & - & 4688 & - & 2.50 \\
\hline Acanthaceae & - & 5.63 & - & 1500 & - & 1.19 \\
\hline Polypodiaceae & - & 6.25 & - & 1938 & - & 1.39 \\
\hline Rubiaceae & 16.25 & - & 9750 & - & 5.80 & - \\
\hline Melastromaceae & 9.38 & - & 3375 & - & 2.70 & - \\
\hline Onocleaceae & - & 10.63 & - & 4875 & - & 2.73 \\
\hline Rubiaceae & 12.50 & - & 5938 & - & 4.01 & - \\
\hline Rubiaceae & - & 14.38 & - & 8063 & - & 4.04 \\
\hline Paniceae & 10.00 & 12.50 & 3188 & 4250 & 2.76 & 2.86 \\
\hline Melastromaceae & 5.00 & - & 5438 & - & 2.33 & - \\
\hline Oxalidaceae & 8.13 & - & 7500 & - & 2.50 & - \\
\hline Poaceae & 13.13 & 17.50 & 13063 & 5250 & 6.17 & 3.84 \\
\hline Piperaceae & - & 6.25 & - & 2500 & - & 1.52 \\
\hline Piperaceae & 14.38 & - & 6000 & - & 4.37 & - \\
\hline Verbenaceae & - & 6.88 & - & 4375 & - & 2.05 \\
\hline Polygonaceae & - & 10.00 & - & 4125 & - & 2.46 \\
\hline Polygonaceae & - & 18.13 & - & 7374 & - & 4.43 \\
\hline Aspidiaceae & - & 20.00 & - & 8500 & - & 4.98 \\
\hline Thelypteridaceae & - & 3.75 & - & 2813 & - & 1.22 \\
\hline Pteridaceae & - & 3.13 & - & 4500 & - & 1.53 \\
\hline Rubiaceae & - & 6.88 & - & 3875 & - & 1.94 \\
\hline Selaginellaceae & 11.25 & - & 8663 & - & 4.91 & - \\
\hline Malvaceae & - & 6.88 & - & 5751 & - & 2.38 \\
\hline Fabaceae & 18.13 & - & 16475 & - & 8.97 & - \\
\hline Melastromaceae & 21.25 & - & 9895 & - & 6.99 & - \\
\hline Melastromaceae & 8.13 & - & 5090 & - & 2.94 & - \\
\hline Asteraceae & 5.63 & 14.38 & 6188 & 5564 & 1.95 & 3.45 \\
\hline Acanthaceae & 15.63 & - & 10813 & - & 5.99 & - \\
\hline Taccaceae & - & 9.38 & - & 4115 & - & 2.37 \\
\hline Scrophulariaceae & - & 14.38 & - & 10188 & - & 4.54 \\
\hline Liliaceae & 5.63 & - & 3974 & - & 1.85 & - \\
\hline Malvaceae & - & 10.63 & - & 5062 & - & 2.77 \\
\hline Violaceae & 3.13 & - & 560 & - & 0.78 & - \\
\hline Violaceae & 6.25 & - & 3650 & - & 1.82 & - \\
\hline Zingiberaceae & 12.50 & - & 6750 & - & 4.24 & - \\
\hline \multirow[t]{2}{*}{ Zingiberaceae } & 4.38 & - & 790 & - & 1.02 & - \\
\hline & - & - & 347563 & 423688 & 200 & 200 \\
\hline
\end{tabular}

